\section{EDUCATION}

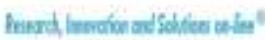

PSYCHOLOGY

$140+1$
Electronic Journal of Research

in Educational Psychology

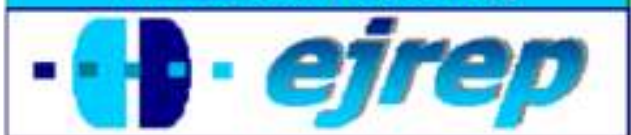

Editorial EOS

\title{
Is there a relationship between pre-service teachers' mathematical values and their teaching anxieties in mathematics?
}

\section{Ersen Yazıcı ${ }^{1}$, Murat Peker ${ }^{2}$, Erhan Ertekin ${ }^{1}$, and Bülent Dilmaç ${ }^{3}$}

${ }^{1}$ Department of Elementary Mathematics Education, Selçuk University, Konya

${ }^{2}$ Department of Elementary Mathematics Education,

Afyon Kocatepe University, Afyonkarahisar

${ }^{3}$ Department of Education Science, Selçuk University, Konya

Turkey

Correspondence: Ersen Yazıcı. Department of Elementary Mathematics Education, Selçuk University, Education Faculty, 42090, Meram / Konya. Turkey. E-mail: ersenyazici@ selcuk.edu.tr

(c) Education \& Psychology I+D+i and Editorial EOS (Spain) 


\begin{abstract}
Introduction. The aim of this study is to investigate the relation between the pre-service teachers' mathematical values and teaching anxieties in mathematics.

Method. The research was carried out on 359 teacher candidates attending the elementary school mathematics, secondary school mathematics and primary school teaching programs. To this end, the 23-item Mathematics Teaching Anxiety Scale and the 34-item Mathematical Values Scale was administered to the pre-service teachers included in the sampling. In the analysis of the data, Pearson Product Moment Correlation Coefficient analysis and regression analysis were utilized to determine the relation between the pre-service teachers' mathematical values and their teaching anxieties in mathematics.
\end{abstract}

Results. As a result of the analysis of data, it was determined that there was a low level, positive correlation between the mathematical values of the pre-service teachers and their mathematics teaching anxieties. According to the regression analysis results, it can be said that constructivist values that are part of the mathematical values are the estimator of mathematics teaching anxieties that arise from self-confidence and attitude towards teaching mathematics.

Discussion and conclusions. Among the mathematical values, the constructivist value preferences of the pre-service teachers directly affect their mathematics teaching anxieties, and can be taken as a sign that it is possible to reduce their mathematics teaching anxieties by affecting the mathematical value preferences of the candidates. Therefore, determining other variables that may affect value preferences of candidates gains importance.

Keywords: mathematics teaching anxiety; mathematical value; pre-service teacher. 


\section{¿Existe una relación entre los valores matemáticos de los futuros maestros y su ansiedad sobre la enseñanza de las matemáticas?}

\section{Resumen}

Introducción. El objetivo de este estudio es investigar la relación entre los valores de los profesores, en formación de la enseñanza matemática y la ansiedad en matemáticas.

Método. La investigación se llevó a cabo con 359 candidatos a maestros que asistieron a las clases de matemática en la escuela primaria, la secundaria, en los programas de enseñanza escolar. Con este fin, se elaboraron 23 preguntas de la enseñanza matemática, se utilizó una Escala de Ansiedad y los 34 ítems de la Escala de valores hacia las matemáticas. Se administró a los maestros de pre-servicio incluidas en el muestreo. En el análisis de los datos, se realizón a través del coeficiente de correlación de producto-momento de Pearson y análisis de regresión. Se utilizaron para determinar la relación entre los valores de los profesores en formación matemática de sus ansiedades y la enseñanza de las matemáticas.

Resultados. Como resultado del análisis de los datos, se determinó que había un bajo nivel de correlación positiva entre los valores matemáticos de los maestros antes del servicio y su ansiedad en la enseñanza de las matemáticas. De acuerdo con los resultados de análisis de regresión, se puede afirmar que los valores constructivista que forman parte de los valores matemáticos son el estimador de la ansiedad en la enseñanza de las matemáticas, que surgen de la autoconfianza y la actitud hacia la enseñanza de las matemáticas.

Discusión y conclusiones. Entre los valores matemáticos, las preferencias de valor constructivista de los maestros antes del servicio afectan directamente a su ansiedad en la nenseñanza de las matemáticas, y puede ser tomado como una señal de que es posible reducir la ansiedad en la enseñanza de las matemáticas, al afectar las preferencias de valor matemático de los candidatos. Por lo tanto, la determinación de otras variables que pueden afectar las preferencias de valor de los candidatos gana importancia.

Palabras clave: enseñanza de las matemáticas ansiedad; valor matemático; formacióninicial de los docentes 


\section{Introduction}

The three basic components of mathematics education are mathematics, teachers and students. These components are not valueless; they are, in reality, value carriers. From a mathematical point of view, they change throughout time, and carry some modern values (Leu \& $\mathrm{Wu}, 2005)$. All people needs to use mathematics, no matter where. Mathematics can be observed in daily life in universal behaviour such as counting, measuring, locating, designing, explaining and playing. These behavioural patterns reflect the culture of the person, and are inevitably affected by the values created by that culture. Unfortunately, until 10 years ago, very little was known about these values and very little was written (Bishop, 2001). In recent years, quite a few studies on values taught in mathematics classes have been carried out (Atweh \& Seah, 2008; Bishop, 2008a, 2008b; Dede, 2006a, 2006b, 2009; Knott, 2007; Leu \& $\mathrm{Wu}, 2005$; Seah, 2005). The word 'value' is used in many contexts. For example, the value of the unknown in an equation, the value of listening to a talk, the ethical value of an individual, all have different meanings (Seah \& Bishop, 2000). According to McConatha and Schnell (1995, p.80), "values are primary constructs which affect an individual's interpretive schema and his or her sense of self, thereby exerting a direct or indirect influence on attitudes, beliefs, feelings, and the perception of the social and political world". Values in mathematics education are the principles or standards of each teacher's choices and judgments concerning the importance or worth of using certain pedagogical identities in his/her classroom teaching of mathematics (Chin \& Lin, 2000).

It is emphasized that more care must be taken regarding the pedagogical values taught to students with mathematical education (Chin \& Lin, 2000). Teachers, students and individuals desiring an education suited to their roles in a more democratic society need to understand the importance of values in mathematical education (Bishop, FitzSimons, Seah, \& Clarkson, 1999). Values in mathematical education are an important component of effective classroom environment. The values in mathematical education are also a powerful tool in knowing how students make their choices, related to mathematics or not (Corrigan, Gunstone, Bishop, \& Clarke, 2004). Values taught during mathematics classes are grouped in three categories, namely, general educational values, mathematical values and values related to mathematics education (Seah \& Bishop, 2000). For example, when a teacher catches a student cheating during a math test, the value he/she will teach the student will be honesty, which is one of the basic values of society, and good behaviour, a general educational value. According to Bishop 
(2001), this value is not related to mathematics education. Teachers' using three different proofs of the Pythagorean Theorem and comparing them is an example of mathematical values. Teachers' asking his/her students to make sure they have done all the calculations in their answers, guessing without using calculator while calculating and then to check their answers can be regarded as an example for values related to mathematics education (Seah \& Bishop, 2000).

Bishop (2001) has classified mathematical values in 6 categories. These values are summarized below (Bishop, 2001, 2008b; Bishop, Clarkson, FitzSimons, \& Seah, 2002): Rationalism: Bishop, (2001), names the basic value people associate with mathematics as rationalism and states that this value comprises logical and theoretical reasoning. The primary signs of this value are deliberation, emphasis of mathematical attestations, different proofs for a theorem. Objectism: The capability of creating symbols and concrete representations in mathematics is called objectism. The emphasis is on encouraging students to display their own symbols and terminologies before those already used in mathematics, using geometrical diagrams to show algebraic relationships, illustrating different numbering systems used throughout history by various cultures, the need for simplicity and brevity in choosing symbols. Control: Many people are aware of the need to act controlled in creating rules, making predictions and stating opinions about situations. Control is one of the reasons why people like mathematics. It has correct answers which can always be checked. Foremost signs of this value are emphasis on not just the correct answers, but the process of checking the answers by students and thinking on the reasons for incorrect answers, encouraging students to understand and analyze the reasons routine calculations and algorithms work, more emphasis on the foundations for these algorithms, always giving examples showing how the mathematical ideas that are taught are used in society. Progress: This value encompasses the advanced level development, generalization and abstraction of mathematics. The emphasis of alternative, non-routine solutions, encouragement of students in reaching generalized ideas from specific examples, illuminating information on the stories of mathematical developments in history are a part of this value. Openness: Another value that arises from the belief of mathematicians in their ideas confirmed by their proofs and by their peers through applications is openness. Having the students disclose their own ideas to the whole class is a good way to develop openness. The main signs of this value are encouragement of students to verify and justify their answers in class, encouragement of students to prepare posters displaying their ideas, giving the students the opportunity to prepare a mathematics magazine or a website for stu- 
dents to post their ideas. Mystery: This is the value that exhibits the relation, patterns and surprises inherent in the structure of mathematics. Signs related to this value are stories of mathematical adventures in the past (for example, the research into the $\pi$ number), stimulating the mathematical imaginations of students with images, art, depictions of infinity and other mathematical mysteries.

It has been observed that some research have been carried out in recent years on the mathematical values of teachers or pre-service teachers (Bishop, 2008b; Bishop, Clarckson, FitzSimons \& Seah, 2002; Dede, 2009). For example, Dede (2009), has reported that primary and secondary school pre-service mathematics teachers have a tendency to conform to constructivist values rather than positivist values. He has also investigated the gender-based differences in the mathematics education values of pre-service teachers and has reached the conclusion that gender was not a factor in the mathematical values of pre-service teachers. It is difficult to change the mathematics education values of teachers (Leu \& Wu, 2005). It has been reported that choices of a teacher based on his/her own values in teaching of mathematical concepts affects the values of the students (Bishop, 2001). Therefore, teachers' and preservice teachers' teaching of mathematics is important for their students. Zerpa, Kajander, and Van Barneveld (2009), have claimed that improving the mathematical knowledge and mathematical values of pre-service teachers before they start practicing in the classroom will develop the mathematical knowledge and values they will bring to the classroom. Otherwise, it has been reported that the negative effects of the values on individuals cause anxiety (FitzSimons, 1999). It has been stated that this anxiety felt by the teachers is transmitted to his/her students (Vinson, 2001).

Besides the mathematical values of pre-service teachers in mathematics education, their teaching anxiety in mathematics is also an important issue under study (Peker, 2006, 2008, 2009a, 2009b, 2009c; Peker \& Halat, 2008, 2009; Peker, Halat \& Mirasyedioğlu, 2010). Teaching anxiety is defined as the anxiety experienced in relation with the teaching process comprising the preparation and implementation of classroom activities (Gardner \& Leak, 1994). And mathematics teaching anxiety can be defined as the stress and anxiety felt by teachers in the teaching of mathematical concepts, theorems, formulas or problem solving (Peker, 2006). It has been reported that mathematics teaching anxiety is an often encountered fear in pre-service teachers (Levine, 1993). Levine (1996) has stated that high levels of mathematics teaching anxiety in pre-service teachers are related to insufficient math knowl- 
edge and bad mathematics learning experiences in the past. At the same time, in other research carried out, it was established that the teaching anxieties of pre-service teachers was dependent on the concrete materials they required in teaching mathematics, that is, the more concrete materials needed, the higher teaching anxiety of the pre-service teachers (Peker, 2008), that the teaching anxieties of pre-service teachers in mathematics was influenced by the teaching methods applied in lectures attended in university (Peker, 2009a, 2009c; Peker \& Halat, 2009), that teaching anxiety differed according to the learning styles of pre-service teachers (Peker, 2009b), and that there is no statistically significant difference according to gender in the mathematics teaching anxieties of pre-service primary school teachers (Peker \& Halat, 2008) and in teaching anxieties of pre-service mathematics teachers (Peker, Halat \& Mirasyedioğlu, 2010).

What kind of relation is there between mathematical values or mathematics education related values and the mathematics teaching anxieties of pre-service teachers? It has been seen that there are no studies conducted on this subject in literature. Therefore, as there are no similar studies in literature, it is necessary to reveal the existence and level of a relation between two variables. For this reason, the purpose of this study is to investigate whether there is a relation between the mathematical values of pre-service teachers and their teaching anxieties in mathematics, and thus to contribute to mathematics education and literature.

\section{Method}

\section{The Model of the Research}

General survey methods was used in this research. According to Karasar (2000), survey models are research methods aiming to describe a past or continuing situation as it is. Here, the event that is the subject of the research is attempted to be defined within its own conditions and as it exists. In a general survey model, in a universe made up of a large number of elements, survey is carried out on the entire universe, or on a group taken from the whole, a sample or paradigm. In this research, convenience sampling (Patton, 1990) was selected as the sampling model. Because with this model, researchers build up a sample that is satisfactory to their specific neeeds (Cohen, Manion \& Morrison, 2000). On the other hand, the most appropriate purposeful sampling strategy to our study among 16 types of purposeful sampling Patton describes is convenience sampling in which available individuals are taken or the cases 
are taken as they occur (Patton, 1990). Whilst it may satisfy the researcher's needs to take this type of sample, it does not pretend to represent the wider population (Cohen et. al, 2000).

\section{Participants}

Research was carried out on 359 pre-service teachers studying in the primary education mathematics teaching, secondary education mathematics teaching and primary school teaching programs in a university in Turkey. $52 \%$ of the participants were pre-service elementary school mathematics teachers, $17 \%$ pre-service secondary school mathematics teachers and $31 \%$ pre-service primary school teachers. The pre-service teachers included in the sampling completed the data collecting tools voluntarily.

\section{Instruments}

In this research, the Mathematics Teaching Anxiety Scale, developed by Peker (2006), and Mathematical Values Scale, developed by Durmuş and Bıçak (2006) were used.

\section{1) Mathematics Teaching Anxiety Scale}

Mathematics Teaching Anxiety Scale (MATAS) is a 5-fold likert-type scale comprising 23 items. The items making up the scale can be answered as I agree absolutely, I agree, I am undecided, I don't agree, and I absolutely don't agree. Negatively phrased items are scored from 5 to 1 , and the positive ones from 1 to 5 . Thus the total points will show the mathematics teaching anxiety points of the pre-service teacher.

In order to realize the validity, Peker (2006) performed the exploratory factor analysis. In result of the exploratory factor analysis, he reported that the MATAS included four factors and four-factor analysis of variance was $56.47 \%$; for each factor, analysis of variance ranged $35.37 \%, 8.55 \%, 6.57 \%$, and $5.97 \%$ respectively. Peker (2006) has introduced MATAS as a 4factor scale. These factors are, anxiety arising from content knowledge, made up of 10 items having factor weights between 0.53 and 0.86 ; anxiety arising from self-confidence, made up of 6 items with factor weights between 0.57 and 0.76; anxiety arising from the attitude towards teaching mathematics, made up of 4 items having factor weights between 0.61 and 0.70; and anxiety arising from pedagogical content knowledge, comprising 3 items with factor 
weights between 0.68 and 0.78. Cronbach Alpha Coefficient was also calculated for the entire scale was as .91; for each factor, alpha ranged $.90, .83, .71$, and .61 respectively, for reliability of the MATAS by Peker. In this study, research sample was similar with Peker's research. Peker (2006) studied on pre-service primary teachers, pre-service elementary and secondary mathematics teachers. Also, this study was carried out on the pre-service primary teachers, pre-service elementary and secondary mathematics teachers. So, we found the same factors in result of the factor analysis. We also found that the reliability coefficient (Cronbach Alpha) of the scale was 0.93 , and the reliability coefficient of the four factors was calculated as 0.88 for the anxiety arising from content knowledge sub-factor, 0.84 for the anxiety arising from selfconfidence sub-factor, 0.92 for the anxiety arising from the attitude towards teaching mathematics sub-factor, and 0.86 for the anxiety arising from pedagogical content knowledge subfactor. Therefore, the MATAS had satisfactory results on validity and reliability analysis.

\section{2) Mathematical Values Scale}

Mathematical Values Scale (MVS) is a 5-fold likert-type scale comprising 34 items. The items making up the scale can be answered as I agree absolutely, I agree, I am undecided, I don't agree, and I absolutely don't agree. Scoring of the answers is from 1 to 5 respectively.

The Mathematical Values Scale, developed by Durmuş and Bıçak (2006), has two main factors, namely positivist values (Postval) and constructivist values (Constval). The scale, initially comprising 40 items, was subjected to a factor analysis, and 6 items with itemtest correlation values below 0.30 were removed, leaving 34 items, 14 in the sub-category of positivist values and 20 in the sub-category of constructivist values, establishing the final 34item form. Cronbach's Alpha coefficient has been used to determine the internal reliability of the scale, and these values are 0.73 for the scale as a whole, 0.64 for the positivist values subcategory and 0.74 for the constructivist values sub-category. The Pearson correlation coefficient calculated between the positivist and constructivist sub-categories has been found as 0.20 .

\section{Statistical Analysis}

In determining the mathematics values and mathematics teaching anxieties of preservice teachers, descriptive statistics such as the total of sub-factor points and standard devia- 
tions obtained from the data collecting tools were used. Correlation was used in determining the relation between the mathematical value preferences of the candidates and their teaching anxiety, and regression analysis to determine whether mathematical values could be used for the estimation of teaching anxieties.

\section{Results}

In the presentation of findings related to the mathematical values and mathematics teaching anxieties, first, the Pearson Product-Moment Correlation Coefficient analysis, carried out to determine the relationship between values and teaching anxiety, then the results of the regression analysis have been given. The correlations between the sub-category scores obtained by scoring the pre-service teachers' answers to MATAS and MVS are shown in Table 1.

Table 1. Correlations between the mathematical values and mathematics teaching anxiety score of pre-service teachers

\begin{tabular}{l|cc}
\hline \multicolumn{1}{c|}{ Value } & $\begin{array}{c}\text { Positivist } \\
\text { Value }\end{array}$ & $\begin{array}{c}\text { Constructivist } \\
\text { Value }\end{array}$ \\
\hline $\begin{array}{l}\text { Sub-category of pre-service teachers' content knowl- } \\
\text { edge in mathematics teaching anxiety }\end{array}$ & 0.09 & $0.11^{*}$ \\
$\begin{array}{l}\text { Sub-category of pre-service teachers' self confidence in } \\
\text { mathematics teaching anxiety }\end{array}$ & 0.05 & $0.17^{*}$ \\
$\begin{array}{l}\text { Sub-category of pre-service teachers' attitude towards } \\
\text { teaching mathematics in mathematics teaching anxiety }\end{array}$ & 0.01 & $0.16^{*}$ \\
$\begin{array}{l}\text { Sub-category of pre-service teachers' pedagogical con- } \\
\text { tent knowledge in mathematics teaching anxiety }\end{array}$ & 0.03 & $0.12^{*}$ \\
\hline
\end{tabular}

According to the findings presented in Table 1, the correlations between the mathematical values of the pre-service teachers and their mathematics teaching anxiety vary between 0.01 and 0.17 . It can be seen that the correlations between the sub-categories of teaching anxiety and positivist values, a sub-category of mathematical values, are not significant. 
However, the correlations between the mathematical values sub-category of constructivist values and all sub-categories of mathematics teaching anxiety have been found significant at $\alpha=0.05$ level. Although all correlations are in positive, they are not at a level that can be called high. This shows that there is a low level positive relationship between the mathematics teaching anxieties of pre-service teachers and their constructivist values.

In order to clarify the relationship between values and teaching anxiety, and to determine if the values could be used to estimate the teaching anxiety, regression analysis has been carried out with each sub-category of values as an independent variable, and each subcategory of teaching anxiety as a dependent variable. The results have been presented in Table 2 , and the following tables, in the order of teaching anxiety sub-categories.

Table 2. Sub-category of pre-service teachers' content knowledge in teaching anxiety

\begin{tabular}{ccccc}
\hline Model & $\mathrm{R}$ & & $\mathrm{R}^{2}$ & $\mathrm{~F}$ \\
\hline Value & 0.124 & 0.02 & 2.786 \\
\hline Variable & $\begin{array}{c}\text { Unstandardized } \\
\text { Beta }\end{array}$ & Standard Error & Standard Beta & $t$ \\
\hline $\begin{array}{c}\text { Positivist Value } \\
\begin{array}{c}\text { Constructivist } \\
\text { Value }\end{array}\end{array}$ & 0.05 & 0.05 & 0.06 & 1.108 \\
\hline
\end{tabular}

According to the regression analysis results given in Table 2, the power of the subcategories of the mathematical values scale to explain the pre-service teachers' content knowledge sub-category in MATAS is only 0.02 . This value has been found not significant at $\alpha=0.05(\mathrm{~F}=2.786)$. That is, it can be said that the preferences of the pre-service teachers regarding mathematical values cannot be used to estimate teaching anxieties arising from content knowledge. Furthermore, when the $t$ values associated with the sub-categories of the value scale are examined, it is seen that the $t$ values calculated for both positivist values and for constructivist values are not significant at $\alpha=0.05$ level $(t=1.108$ and $t=1.729)$. 
Table 3. Sub-category of pre-service teachers' self-confidence in teaching anxiety

\begin{tabular}{ccccc}
\hline Model & $\mathrm{R}$ & $\mathrm{\textrm {R } ^ { 2 }}$ & $\mathrm{F}$ \\
\hline Value & 0.174 & 0.03 & $5.547^{* *}$ \\
\hline Variable & $\begin{array}{c}\text { Unstandardized } \\
\text { Beta }\end{array}$ & Standard Error & Standard Beta & $t$ \\
\hline $\begin{array}{c}\text { Positivist Value } \\
\text { Constructivist } \\
\text { Value }\end{array}$ & 0.01 & 0.03 & 0.01 & 0.116 \\
\hline
\end{tabular}

According to the regression analysis results given in Table 3, the power of the subcategories of the mathematical values scale to explain the pre-service teachers' selfconfidence sub-category in MATAS is 0.03 . This value has been found significant at $\alpha=0.01$ level $(\mathrm{F}=5.547)$. Based on this, it can be said that the scores of the sub-categories of the value scale may be used to estimate the pre-service teachers' teaching anxieties arising from self-confidence. Furthermore, when the $t$ values associated with the sub-categories of the value scale are examined, it is seen that the $t$ value for the constructivist value sub-category is significant at $\alpha=0.01$ level ( $t=3.187)$. That is, the constructivist value scores of the candidates are a component of the equation constructed to estimate their teaching anxieties.

Table 4. Sub-category of pre-service teachers' attitude in teaching anxiety

\begin{tabular}{ccccc}
\hline Model & $\mathrm{R}$ & $\mathrm{R}^{2}$ & $\mathrm{~F}$ \\
\hline Value & 0.168 & 0.03 & $5.171^{* *}$ \\
\hline Variable & $\begin{array}{c}\text { Unstandardized } \\
\text { Beta }\end{array}$ & Standard Error & Standard Beta & $t$ \\
\hline $\begin{array}{c}\text { Positivist Value } \\
\text { Constructivist } \\
\text { Value }\end{array}$ & -0.02 & 0.02 & -0.04 & -0.664 \\
\hline
\end{tabular}


According to the regression analysis results given in Table 4, the power of the subcategories of the mathematical values scale to explain the pre-service teachers' attitude towards teaching mathematics sub-category in MATAS is 0.03 . This value has been found significant at $\alpha=0.01$ level $(\mathrm{F}=5.171)$. Therefore, it is possible to say that the sub-categories of the value scale can be used to estimate the teaching anxieties of the candidates arising from their attitude towards teaching mathematics. When the $t$ scores associated with the subcategories of the value scale are examined, it can be seen that the $t$ value of the constructivist values is significant at $\alpha=0.01$ level $(t=3.211)$, and the score for the positivist values is not significant at $\alpha=0.05$.

Table 5. Sub-category of pre-service teachers' pedagogical content knowledge

\begin{tabular}{ccccc}
\multicolumn{5}{c}{ in teaching anxiety } \\
\hline Model & $\mathrm{R}$ & \multicolumn{2}{c}{$\mathrm{R}^{2}$} & $\mathrm{~F}$ \\
\hline Value & 0.119 & 0.01 & 2.552 \\
\hline Variable & $\begin{array}{c}\text { Unstandardized } \\
\text { Beta }\end{array}$ & Standard Error & Standard Beta & $t$ \\
\hline $\begin{array}{c}\text { Positivist Value } \\
\text { Constructivist } \\
\text { Value }\end{array}$ & 0.01 & 0.02 & 0.01 & 0.041 \\
\hline
\end{tabular}

According to the regression analysis results given in Table 5, the power of the subcategories of the mathematical values scale to explain the pre-service teachers' field education knowledge sub-category in MATAS is only 0.01 . This value has been found not significant at $\alpha=0.05$ level $(\mathrm{F}=2.172)$. That is, there is no evidence that the value scale significantly explains the sub-category of pedagogical content knowledge in pre-service teachers' teaching anxieties. However, when the $t$ values associated with the sub-categories of the value scale are examined, it is seen that, similar to the findings presented above for the other sub-categories, the $t$ value for the constructivist value sub-category has been found significant at $\alpha=0.05$ ( $t=$ 2.172). Even though the calculated F score is not significant, it can be a sign that the constructivist value scores of the candidates may be used in estimating their pedagogical content knowledge in teaching anxiety. 


\section{Discussion and conclusions}

This research intends to determine the relationship between the pre-service teachers' mathematical values and their teaching anxieties in mathematics.

When the findings regarding the determination of the correlation between mathematical values and teaching anxieties are taken into consideration, it is possible to say that a relationship exists between the constructivist value preferences of the pre-service teachers and their mathematics teaching anxieties that is positive, low level and significant at the $\alpha=0.05$ level, according to both the correlation and regression analysis results. According to the regression analysis results, it can be said that constructivist values that are part of the mathematical values are the estimator of mathematics teaching anxieties that arise from selfconfidence and attitude towards teaching mathematics. This shows that among the mathematical values, the constructivist value preferences of pre-service teachers directly affect their mathematics teaching anxieties, and can be taken as a sign that it is possible to reduce their mathematics teaching anxieties by affecting the mathematical value preferences of the candidates. Therefore, determining other variables that may affect value preferences of candidates gains importance.

The fact that while there is a significant relationship between the constructivist values and anxiety, there is no significant relationship between positivist values and mathematics teaching anxiety. However mathematics teaching anxiety can be explained by saying that individuals who have mainly constructivist values are more anxious about teaching mathematics. It comes to mind that organizing learning activities based on constructivist philosophy in learning-teaching environments is more difficult than organizing activities based on positivist approaches. Moreover, educators in training, do not receive sufficient training in the application of the principles and recommendations of constructivist philosophy with clear examples in college classes (Scheurman, 1997). So, it may be effective in increasing the mathematics teaching anxieties of pre-service teachers with constructivist values. While this situation shows the relation between teaching anxiety and constructivist values, when it is considered that in today's mathematics education the foundation is the creation of constructivist learning environments and the construction of knowledge by the students (Scheurman, 1997), it also indicates that it is necessary to determine the other variables that increase the teaching anxie- 
ties of pre-service teachers and use all these in activities targeting the reduction of the candidates' anxieties.

The fact that constructivist values estimate especially mathematics teaching anxieties arising from self-confidence and attitude may be explained by saying that the pre-service teachers do not have the confidence in themselves to teach in accordance with constructivist philosophy, and as a result of this lack of confidence, they develop teaching anxiety arising from their negative attitude towards teaching mathematics. The results of a research by Dorman and Adams (2004) does not support the theoretical view that the constructivist approach in learning and teaching will compensate for the insufficiencies of the positivist approach. In fact, the high level of anxiety of the pre-service teachers with constructivist values in at least two categories can be considered findings regarding potential future complications in the classroom environment, when the relationship between anxiety and behaviour (Uusimaki \& Nason, 2004) is considered. Greenwood (1984:663) stated that the principal cause of maths anxiety lies in the teaching methodologies used to convey basic mathematical skills. $\mathrm{He}$ asserted that the "explain - practise - memorize" teaching paradigm is the real source of the maths anxiety syndrome. He states that teachers create anxiety by placing too much emphasis on memorising formulae, learning mathematics through drill and practice, applying rotememorised rules and setting out work in the traditional way (cited in Thijsse, 2002). Similarly, teaching of constructivist approach as theoretically in special teaching methods course may be effective in construction of math teaching anxiety of preservice math teachers. In this regard, the results of our research show parallelisms with the findings of Dorman and Adams (2004). At this point, it can be stated that while mathematics educators demand constructivist philosophy based teaching from pre-service teachers, they should particularly present plenty of model lessons.

So, according to our research findings; it looks rather like those with mathematical constuctivist teaching values are more susceptible to developing math teaching anxiety than those with a positivist teaching philosophy. In the light of the results above, an investigation of the relationship between the mathematical values and teaching anxieties of pre-service teachers with experimental studies including suitable classroom activities for constructivist and positivist approaches will clarify the findings of our research. 


\section{References}

Atweh, B. \& Seah, W.T. (2008). Theorising values and their study in mathematics education. Paper presented at the Australian Association for Research in Education Conference, Fremontle, Australia.

Bishop, A.J. (2001). What values do you teach when you teach mathematics? Teaching Children Mathematics, 7(6), 346-349.

Bishop, A.J. (2008a). Values in mathematics and science education: Similarities and differences. The Montana Mathematics Enthusiast, 5(1), 47-57.

Bishop, A.J. (2008b). Teachers' mathematical values for developing mathematical thinking in classrooms: Theory, Research and Policy. The Mathematics Educator, 11(1/2), 79-88.

Bishop, A.J., Clarkson, P.C., FitzSimons, G.E., \& Seah, W.T. (2002). Studying values in mathematics education: Aspects of the VAMP Project. In Novotná, J. (Eds.). Proceedings of European Research in Mathematics Education II, (pp. 368-376). Prague: Charles University, Faculty of Education,

Bishop, A., FitzSimons, G., Seah, W.T., \& Clarkson, P. (1999). Values in mathematics education: Making values teaching explicit in the mathematics classroom. Paper Presented at the Combined Annual Meeting of the Australian Association for Research in Education and the New Zealand Association for Research in Education. November 29 - December 2, Melbourne, Australia.

Chin, C. \& Lin, F.L. (2000). A case study of a mathematics teacher's pedagogical values: Use of a methodological framework of interpretation and reflection. Proceedings of the National Science Council, 10(2), 90-101.

Cohen, L., Manion, L. \& Morrison, K. (2000). Research Methods in Education (5 ${ }^{\text {th }}$ Edition). London: RoutledgeFalmer.

Corrigan, D.J., Gunstone, R.F., Bishop, A., \& Clarke, B. (2004). Values in science and mathematics education; mapping the relationships between pedagogical practices and student outcomes. Paper presented at Summer School of The European Science Educational Research Association, August, Mulheim, Germany.

Dede, Y. (2006a). Values in Turkish middle school mathematics textbooks. Quality \& Quantity, 40, 331-359. 
Dede, Y. (2006b). Mathematics educational values of college students' towards function concept. Eurasia Journal of Mathematics, Science and Technology Education, 2(1), 82102.

Dede, Y. (2009). Turkish preservice mathematics teachers' mathematical values: Positivist and constructivist values. Scientific Research and Essays, 4(11), 1229-1235.

Dorman, J. \& Adams, J. (2004). Associations between students' perceptions of classroom environment and academic efficacy in Australian and British secondary schools. International Journal of Research \& Method in Education, 27(1), 69-85.

Durmuş, S. \& Biçak, B. (2006). A scale for mathematics and mathematics educational values of pre-service teachers. 3rd International Conference on Teaching of Mathematics at the Undergraduate Level, June 30- July 5, Istanbul, Turkey.

FitzSimons, G. E. (1999). Values, vocational education and mathematics: Linking research with practice. In Changing practice through research: Changing research through practice. Proceedings of the $7^{\text {th }}$ Annual International Conference on Post-Compulsory Education and Training, Vol. 3, pp. 11-21. Brisbane: Centre for Learning and Work Research, Griffith University.

Gardner, L. \& Leak, G. (1994). Characteristics and correlates of teaching anxiety among college psychology teachers. Teaching of Psychology, 21(1), 28-32.

Karasar, N. (2000). Scientific Research Methods. Ankara: Nobel Publications.

Knott, L. (2007). Issues of status and values in the professional development of mathematics teachers. The Montana Mathematics Enthusiast, Monograph 1, 99-108.

Leu, Y.C. \& Wu, C.J. (2005). Investigation on an elementary teacher's mathematics pedagogical values through her approach to students' errors. In Chick, H. L. \& Vincent, J. L. (Eds.). Proceedings of the $29^{\text {th }}$ Conference of the International Group for the Psychology of Mathematics Education, Vol. 3, pp. 249-256. Melbourne: PME.

Levine, G. (1993). Prior mathematics history, anticipated mathematics teaching style, and anxiety for teaching mathematics among pre-service elementary school teachers. Paper presented at the Annual Meeting of the International Group for Psychology of Mathematics Education, North American Chapter. (ERIC Document Reproduction Service No. ED373972). 
Levine, G. (1996). Variability in anxiety for teaching mathematics among pre-service elementary school teachers enrolled in a mathematics course. Paper presented at the Annual Meeting of the American Educational Research Assocation in New York. (ERIC Document Reproduction Service No. ED398067).

McConatha, J.T. \& Schnell, F. (1995). The confluence of values: Implications for educational research and policy. Educational Practice and Theory, 17(2), 79-83.

Patton, M.Q. (1990). Qualitative Evaluation and Research Methods. SAGE Publications. Newbury Park London New Delhi.

Peker, M. (2006). Development of the mathematics teaching anxiety scale. Educational Sciences and Application, 9, 73-92.

Peker, M. (2008). Educational programs and mathematics teaching anxieties of pre-service teachers. VIII. National Science and Mathematics Education Congress, 27-29 August, Bolu.

Peker, M. (2009a). The use of expanded microteaching for reducing pre-service teachers' teaching anxiety about mathematics. Scientific Research and Essays, 4(9), 872-880.

Peker, M. (2009b). Pre-service teachers' teaching anxiety about mathematics and Their learning styles. Eurasia Journal of Mathematics, Science \& Technology Education, 5(4), 335-345.

Peker, M. (2009c). The effects of an instruction using problem solving strategies in Mathematics on the teaching anxiety level of the pre-service primary school teachers. The New Educational Review, 19(3-4), 95-114.

Peker, M. \& Halat, E. (2008). The pre-service elementary school teachers' mathematics teaching anxiety and gender, The European Conference on Educational Research, 1012 September, Goteborg, Sweden.

Peker, M. \& Halat, E. (2009). Teaching anxiety and the mathematical representations developed through WebQuest and spreadsheet activities. Journal of Applied Sciences, 9(7), 1301-1308.

Peker, M., Halat, E. \& Mirasyedioğlu, Ş. (2010). Gender related differences in mathematics teaching anxiety. The Mathematics Educator, 12(2), 125-140. 
Seah, W. T. (2005). Negotiating about perceived value differences in mathematics teaching: the case of immigrant teachers in Australia. In Chick, H. L. \& Vincent, J. L. (Eds.). Proceedings of the 29th Conference of the International Group for the Psychology of Mathematics Education, Vol. 4 (pp. 145-152). Melbourne: PME.

Seah, W. T., \& Bishop, A. J. (2000). Values in mathematics textbooks: A view through two Australasian regions. Paper presented at the 81st Annual Meeting of the American Educational Research Association, April 24-28, New Orleans, LA.

Scheurman, G. (1997). Using principles of constructivism to promote reflective judgment: a model lesson. Journal on Excellence in College Teaching, 8(2), 63-86.

Thijsse, L.J. (2002). The effects of a structured teaching method on mathematics anxiety and achievement of grade eight learners. Master Thesis, University of South Africa.

Uusimaki, L. \& Nason, R. (2004). Causes underlying pre-service teachers' negative beliefs and anxieties about mathematics. Proceedings of the 28th Conference of the International Group for the Psychology of Mathematics Education, 4, 369-376. (ERIC Document Reproduction Service No. ED489664).

Vinson, B. M. (2001). A comparison of preservice teachers' mathematics anxiety before and after a methods class emphasizing manipulatives. Early Childhood Education Journal, 29(2), 89-94.

Zerpa, C., Kajander, A., \& Van Barneveld, C. (2009). Factors that impact preservice teachers' growth in conceptual mathematical knowledge during a mathematics methods course. International Electronic Journal of Mathematics Education, 4(2), 57-76. 
Ersen Yazıc1 et al.

[This page intentionally left blank] 